\title{
THE
}

\section{Reversible Graphite Anode Cycling with PC-Based Electrolytes Enabled by Added Sulfur Trioxide Complexes}

Julien Demeaux

Yingnan Dong

Brett L. Lucht

University of Rhode Island, blucht@uri.edu

Follow this and additional works at: https://digitalcommons.uri.edu/chm_facpubs

Creative Commons License

\section{(c) (7)}

This work is licensed under a Creative Commons Attribution 4.0 License.

\section{Citation/Publisher Attribution}

Demeaux, J., Dong, Y., \& Lucht, B. L. (2017). Reversible Graphite Anode Cycling with PC-Based Electrolytes Enabled by Added Sulfur Trioxide Complexes. J. Electrochem. Soc., 164(7), A1352-A1360. doi: 10.1149/ 2.0171707jes

Available at: http://dx.doi.org/10.1149/2.0171707jes 


\title{
Reversible Graphite Anode Cycling with PC-Based Electrolytes Enabled by Added Sulfur Trioxide Complexes
}

\author{
Julien Demeaux, Yingnan Dong, and Brett L. Lucht*, \\ Department of Chemistry, University of Rhode Island, Kingston, Rhode Island 02881, USA
}

\begin{abstract}
Pyridine sulfur trioxide $\left(\mathrm{PyrSO}_{3}\right)$, trimethyl amine sulfur trioxide $\left(\mathrm{Me}_{3} \mathrm{NSO}_{3}\right)$, and triethyl amine sulfur trioxide $\left(\mathrm{Et}_{3} \mathrm{NSO}_{3}\right)$ complexes have been investigated as electrolyte additives for lithium ion batteries. Incorporation of 0.5 to $2.0 \%$ of the $\mathrm{SO}_{3}$ complexes into a PC/EMC (1:1 v/v) $1 \mathrm{M} \mathrm{LiPF}_{6}$ baseline electrolyte affords reversible cycling of graphite anodes confirming generation of a stable Solid Electrolyte Interphase (SEI). Good cycling performance is observed for graphite/ $\mathrm{LiNi}_{0.5} \mathrm{Mn}_{1.5} \mathrm{O}_{4}$ cells cycled to high potential ( $4.8 \mathrm{~V}$ vs $\mathrm{Li}$ ) containing PC based electrolyte with added $\mathrm{SO}_{3}$ complexes. Ex-situ surface analysis via X-ray Photoelectron Spectroscopy (XPS) of the anodes reveals $\mathrm{SO}_{3}$ complex reduction on the surface of the graphite anode generates a sulfur-based SEI containing sulfites, sulfide, and sulfate species. The presence of the sulfur containing species is likely critical for the stability of the SEI. Ex-situ XPS analyses of the $\mathrm{LiNi}_{0.5} \mathrm{Mn}_{1.5} \mathrm{O}_{4}$ cathodes suggest that reaction of $\mathrm{Me}_{3} \mathrm{NSO}_{3}$ or $\mathrm{Et}_{3} \mathrm{NSO}_{3}$ complexes at high potential result in the generation of a stable passivation layer which affords good capacity retention and coulombic efficiency. (C) The Author(s) 2017. Published by ECS. This is an open access article distributed under the terms of the Creative Commons Attribution 4.0 License (CC BY, http://creativecommons.org/licenses/by/4.0/), which permits unrestricted reuse of the work in any medium, provided the original work is properly cited. [DOI: 10.1149/2.0171707jes] All rights reserved.

(cc) BY
\end{abstract}

Manuscript submitted March 20, 2017; revised manuscript received April 18, 2017. Published April 29, 2017.

The standard anode material in most commercial lithium ion batteries is graphite due to good specific capacity, low volumetric expansion upon $\mathrm{Li}^{+}$intercalation, relatively flat potential profile, excellent cyclability, and low cost. However, the reduction potential of lithiated graphite is below the stability window of most organic solvents and thus requires the formation of a Solid Electrolyte Interphase (SEI). ${ }^{1,2}$ Only a few electrolytes result in the formation of a stable SEI on graphite and most of these electrolytes include ethylene carbonate (EC) due to the critical role of EC in SEI formation. ${ }^{3}$ An alternative solvent, propylene carbonate (PC), has been already extensively studied for use in lithium-ion batteries due to its favorable physical properties: high relative permittivity $(\varepsilon=64.96)$ and wide operating temperature range $\left(\mathrm{mp}=-55^{\circ} \mathrm{C}, \mathrm{bp}=240^{\circ} \mathrm{C}\right) .^{2}$ However, reduction of PC does not generate a stable SEI on graphite leading to continuous electrolyte reduction and graphite exfoliation. In addition, EC has recently been reported to have high reactivity with the surface of cathodes operating at high potential. ${ }^{4,5}$

In order to use PC based electrolytes an electrolyte additive is required to assist with SEI formation. ${ }^{6}$ One type of additive which frequently stabilizes the SEI are sulfur-based compounds, ${ }^{7}$ including $\mathrm{SO}_{2},{ }^{8,9} \mathrm{CS}_{2},{ }^{10}$ polysulfides $\mathrm{S}_{\mathrm{x}}{ }^{2-},{ }^{11,12}$ cyclic alkyl sulfites, such as ethylene sulfite, ${ }^{13}$ propylene sulfite, ${ }^{14}$ and aryl sulfites, ${ }^{14}$ propane sultone, ${ }^{15}$ butyl sultone, ${ }^{16}$ functionalized sulfones, ${ }^{17}$ and sulfates. ${ }^{18}$ All of these sulfur compounds are soluble in the organic electrolytes, but anodic unstable at high potential. ${ }^{6}$ Propane sultone is one of the most widely investigated sulfur based additives and has been reported to improve $\mathrm{Li}^{+}$conduction in the anode SEI. However, due to toxicity concerns there is an interest in finding an alternative to PS. Previously reported ex-situ surface analysis of graphite anodes cycled with PS suggests that the primary reduction product of PS is lithium propane sulfonate $\left(\mathrm{RSO}_{3} \mathrm{Li}\right){ }^{19,20}$ In an effort to develop Additives for Designed Surface Modification (ADSM) ${ }^{21}$ novel $\mathrm{SO}_{3}$ based additives have been developed to generate similar reduction products to the lithium alkyl sulfonates generated from the reduction of PS.

Sulfur trioxide complexes, have been investigated as novel additives for PC/EMC (ethyl methyl carbonate) $1 \mathrm{M} \mathrm{LiPF}_{6}$ electrolyte. The chemical structures of pyridine sulfur trioxide $\left(\mathrm{PyrSO}_{3}\right),{ }^{22}$ trimethyl amine sulfur trioxide $\left(\mathrm{Me}_{3} \mathrm{NSO}_{3}\right)$, and triethyl amine sulfur trioxide $\left(\mathrm{Et}_{3} \mathrm{NSO}_{3}\right)$ complexes are provided in Figure 1.

The complexes are bifunctional and combine the advantages of both a Lewis base (pyridine, trimethyl amine, or triethylamine) which inhibits $\mathrm{LiPF}_{6}$ decomposition ${ }^{23}$ and an anode film forming agent $\left(\mathrm{SO}_{3}\right)$ which improves cycling stability on graphite through modification of

\footnotetext{
*Electrochemical Society Member.
}

${ }^{\text {z} E-m a i l: ~ b l u c h t @ c h m . u r i . e d u ~}$ the SEI via incorporation of the $\mathrm{SO}_{3}$ reduction products. ${ }^{11,22}$ Coin cells composed of Graphite/Li and $\mathrm{LiNi}_{0.5} \mathrm{Mn}_{1.5} \mathrm{O}_{4} /$ Graphite have been prepared and cycled with the PC-based electrolyte containing the $\mathrm{SO}_{3}$ complexes in order to study the ability of the additives to generate passivation layers on either the graphite anode and/or the high voltage spinel cathode. A systematic XPS study conducted after cycling shows that the surface chemistry of both electrodes are modified with the added $\mathrm{SO}_{3}$ complexes.

\section{Experimental}

The levels of HOMO and LUMO energies were performed on isolated $\mathrm{EMC}, \mathrm{PC}, \mathrm{PyrSO}_{3}, \mathrm{Me}_{3} \mathrm{NSO}_{3}$, and $\mathrm{Et}_{3} \mathrm{NSO}_{3}$ in the gas phase using the Gaussian 03 package. ${ }^{24} \mathrm{HOMO}$ and LUMO energies were obtained with the B3LYP/6-311+G(2d,p) basis set.

Coin cells were assembled with 2032-type coin cell parts from MTI, including SUS 304 Al- clad cases, SUS 316L caps, PP gaskets, disk spacers of $15.5 \mathrm{~mm}$ diameter and $1.0 \mathrm{~mm}$ of thickness, and wave springs of $15 \mathrm{~mm}$ diameter and $1.4 \mathrm{~mm}$ of thickness.

The cells were built with commercially coated electrodes: $\mathrm{LiNi}_{0.5} \mathrm{Mn}_{1.5} \mathrm{O}_{4}(\mathrm{~d}=14.7 \mathrm{~mm})$ and graphite anode $(\mathrm{d}=15.0 \mathrm{~mm})$, a piece of Whatman glass fiber $(\mathrm{d}=19 \mathrm{~mm})$ with $80 \mu \mathrm{L}$ of electrolyte in an Argon-filled glove box. The water content was less than $0.1 \mathrm{ppm}$. The baseline electrolyte was $1.0 \mathrm{M} \mathrm{LiPF}_{6}$ in PC/EMC (1/1 $\mathrm{v} / \mathrm{v})$. Battery grade carbonate solvents and lithium hexafluorophosphate $\left(\mathrm{LiPF}_{6}\right)$ were obtained from BASF. Pyridine $(98 \%)$, trimethylamine $(95 \%)$, and triethylamine $(95 \%)$ sulfur trioxide complexes were obtained from Sigma Aldrich and added as $2.0 \%, 1.0 \%$, or $0.5 \%$ weight percent of the total mass of electrolyte, all three additives can be dissolved in baseline electrolyte easily up to $2 \%$.

Cells were cycled at $25^{\circ} \mathrm{C}$ at the $\mathrm{C} / 5$ rate on Arbin Instruments potentiostats following a CC-CV protocol. A constant current (CC) charge was applied to reach the desired potential. This potential was maintained (CV) until the current decreased down to $10 \%$ of the

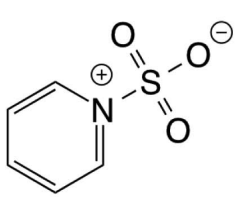

Pyr-SO<smiles>CN(C)S(=O)(=O)[O-]</smiles>

$\mathrm{Me}_{3} \mathrm{NSO}_{3}$

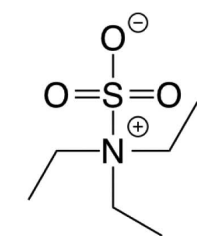

$\mathrm{Et}_{3} \mathrm{NSO}_{3}$
Figure 1. Sulfur trioxide complexes used as additives in the PC/EMC (1/1 v/v) $1 \mathrm{M} \mathrm{LiPF}_{6}$ baseline electrolyte. 


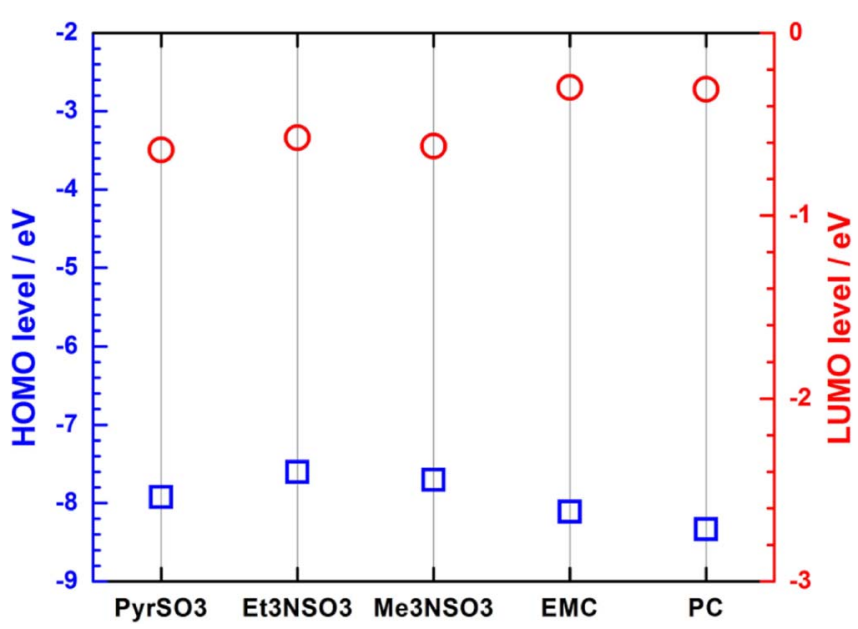

Figure 2. HOMO and LUMO levels of $\mathrm{PyrSO}_{3}, \mathrm{Et}_{3} \mathrm{NSO}_{3}$, and $\mathrm{Me}_{3} \mathrm{NSO}_{3}$ calculated by DFT (Gaussian 03) and the B3LYP/6-311+G(2d,p) basis set.

applied charging current for a maximum duration of 1 hour. The temperature was controlled with a Fisher Scientific Isotemp Incubator. Formation cycling of graphite cells was as follows: 5 cycles, 1 cycle at $\mathrm{C} / 20$ rate, 2 cycles at $\mathrm{C} / 10$, and 2 cycles at $\mathrm{C} / 5$ rate at $25^{\circ} \mathrm{C}$. The remaining cycles were performed at a cycling rate of $\mathrm{C} / 5$. Cycling was conducted in the $4.80-3.30 \mathrm{~V}$ potential range in the case of $\mathrm{LiNi}_{0.5} \mathrm{Mn}_{1.5} \mathrm{O}_{4} /$ graphite cells.

XPS measurements were carried out using a ThermoFisher KAlpha spectrometer, under focused monochromatised $\mathrm{Al} \mathrm{K} \alpha$ radiation $(\mathrm{h} \nu=1486.6 \mathrm{eV})$. Cells were disassembled in the glove box and electrode samples were rinsed 3 times $(3 \times 500 \mu \mathrm{L})$ with anhydrous DMC and dried under vacuum at room temperature for 10 minutes. A vacuum transfer vessel (provided by ThermoFisher) was used to avoid any contact with air/moisture. Peaks were recorded with constant pass energy of $50 \mathrm{eV}$ with energy resolution of $50 \mathrm{meV}$ and charge neutralization. The peak positions and areas were optimized by a weighted least squares fitting method using $70 \%$ Gaussian, $30 \%$ Lorentzian line shapes using the Avantage (ThermoFisher) software.

\section{Results and Discussion}

HOMO and LUMO energy levels determined by DFT calculations.-HOMO and LUMO energy levels are calculated by DFT using the B3LYP/6-311+G(2d,p) basis set to evaluate relative oxidation and reduction potentials of sulfur trioxide complexes, as compared to EMC and PC. Results of HOMO and LUMO levels are depicted in Figure 2.

As seen from Figure 2, the HOMO levels of $\mathrm{PyrSO}_{3}, \mathrm{Et}_{3} \mathrm{NSO}_{3}$, and $\mathrm{Me}_{3} \mathrm{NSO}_{3}$ are higher than the HOMO levels of EMC and PC. This suggests that the sulfur trioxide complexes are more easily oxidized than EMC or PC. Oxidation at high potential could result in modification and passivation of the cathode surface.

LUMO levels of the three sulfur trioxide complexes are similar. They have lower LUMO energies than EMC and PC (Figure 2), suggesting that they are more easily reduced than the carbonates. Their reduction at low potential should modify the SEI on graphite at low potential.

Graphite half-cells._Electrochemical cycling.-Since $\mathrm{PyrSO}_{3}$, $\mathrm{Et}_{3} \mathrm{NSO}_{3}$, and $\mathrm{Me}_{3} \mathrm{NSO}_{3}$ are the theoretically more easily reduced than $\mathrm{PC}$ and EMC and the reduction products are likely similar to the reduction products of PS as described above, they are potentially interesting additives for surface modification of the graphite anode. One method to investigate efficient passivation of graphite is to incorporate the additive into a PC-based electrolyte. It is well known that PC is continuously reduced at $0.8 \mathrm{~V}$ vs. $\mathrm{Li}^{\prime} / \mathrm{Li}^{+}$with little $\mathrm{Li}^{+}$insertion and significant exfoliation of the graphite. ${ }^{25}$
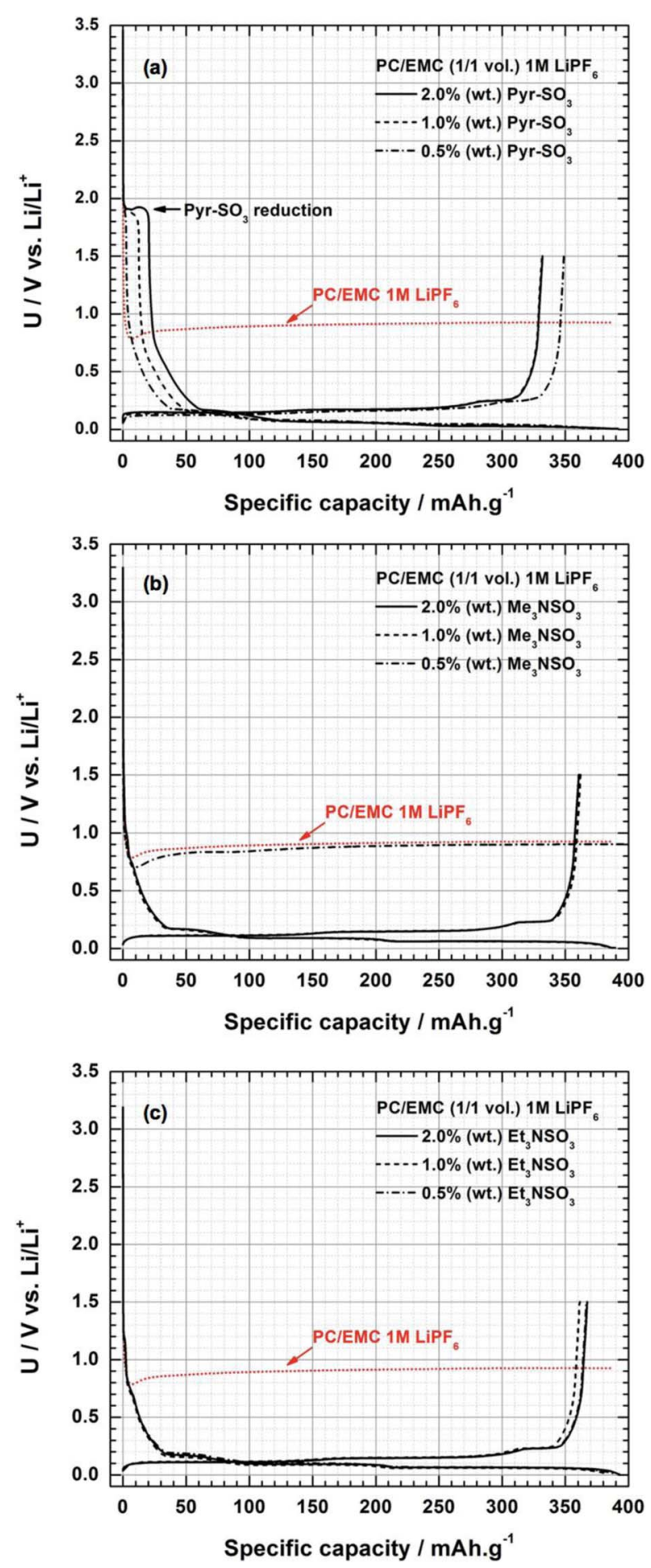

Figure 3. Voltage profile of the first cycle of Graphite/Li half-cells at $25^{\circ} \mathrm{C}$ (C/20, cutoff limits of $0.005 \mathrm{~V}$ vs. $\mathrm{Li}^{2} / \mathrm{Li}^{+}$and $1.5 \mathrm{~V}$ vs. $\left.\mathrm{Li} / \mathrm{Li}^{+}\right)$using PC/EMC (1/1 vol.) $\mathrm{LiPF}_{6} 1 \mathrm{M}$ as the baseline electrolyte with the (a) $\mathrm{PyrSO}_{3}$, (b) $\mathrm{Me}_{3} \mathrm{NSO}_{3}$, and (c) $\mathrm{Et}_{3} \mathrm{NSO}_{3}$ additives (concentrations of $2.0 \%, 1.0 \%$, and $0.5 \%(\mathrm{wt}))$.

The first cycle of Graphite/Li cells with PC based electrolyte containing added $\mathrm{PyrSO}_{3}, \mathrm{Me}_{3} \mathrm{NSO}_{3}$, or $\mathrm{Et}_{3} \mathrm{NSO}_{3}$ is presented in Figure 3. Continuous electrolyte reduction is observed for the baseline PC electrolyte at $0.8 \mathrm{~V}$ vs. $\mathrm{Li} / \mathrm{Li}^{+}$due to a lack of passivation of the graphite electrode (Figures $3 \mathrm{a}, 3 \mathrm{~b}$, and $3 \mathrm{c}$ ). ${ }^{26}$

Incorporation of $\mathrm{PyrSO}_{3}$ to the baseline formulation results in the appearance of a new shoulder at $1.9 \mathrm{~V}$ vs. $\mathrm{Li} / \mathrm{Li}^{+}$. The capacity of 
Table I. Relative atomic percentage (\%) of selected elements at the surface of the graphite electrodes after 1 cycle in $\mathrm{Graphite} / \mathrm{Li}$ cells at $25^{\circ} \mathrm{C}$. Relative atomic concentration of elements present at the fresh graphite electrode is also added for comparison.

\begin{tabular}{|c|c|c|c|c|c|c|c|c|}
\hline \multicolumn{2}{|c|}{ Additive concentration } & $\mathrm{C} 1 \mathrm{~s}$ & F 1s & $\mathrm{O} 1 \mathrm{~s}$ & Li 1s & S 2p & $\mathrm{N} 1 \mathrm{~s}$ & P $2 p$ \\
\hline \multicolumn{2}{|c|}{ Fresh graphite } & 85 & - & 15 & - & - & - & - \\
\hline \multirow[t]{3}{*}{$\mathrm{PyrSO}_{3}$} & $2.0 \%(w t)$ & 14 & 26 & 23 & 28 & 7 & 1 & 2 \\
\hline & $1.0 \%(\mathrm{wt})$ & 15 & 25 & 21 & 29 & 7 & 1 & 2 \\
\hline & $0.5 \%(w t)$ & 18 & 27 & 19 & 28 & 4 & 1 & 3 \\
\hline \multirow[t]{3}{*}{$\mathrm{Me}_{3} \mathrm{NSO}_{3}$} & $2.0 \%(w t)$ & 25 & 20 & 23 & 28 & 2 & 0 & 2 \\
\hline & $1.0 \%(\mathrm{wt})$ & 33 & 23 & 19 & 22 & 2 & 0 & 2 \\
\hline & $0.5 \%(\mathrm{wt})$ & 20 & 37 & 5 & 37 & 0 & 0 & 1 \\
\hline \multirow[t]{3}{*}{$\mathrm{Et}_{3} \mathrm{NSO}_{3}$} & $2.0 \%(\mathrm{wt})$ & 20 & 30 & 17 & 28 & 2 & 0 & 2 \\
\hline & $1.0 \%(w t)$ & 22 & 30 & 16 & 28 & 2 & 0 & 2 \\
\hline & $0.5 \%$ (wt) & 20 & 32 & 14 & 31 & 1 & 0 & 2 \\
\hline
\end{tabular}

the shoulder systematically increases from $5 \mathrm{mAh} . \mathrm{g}^{-1}$ to $30 \mathrm{mAh} \cdot \mathrm{g}^{-1}$ as the concentration of the additive in the electrolyte is increased (Figure 3a). The additive reduction allows $\mathrm{Li}^{+}$insertion into the graphite electrode and prevents further decomposition of the carbonate solvents. Excellent reversibility toward $\mathrm{Li}^{+}$insertion/extraction of graphite is also achieved with $84.7 \%, 87.9 \%$, and $91.7 \%$ coulombic efficiency for electrolytes with $\mathrm{PyrSO}_{3}$ concentrations of $2.0 \%$ (wt), $1.0 \%$ (wt), and $0.5 \%$ (wt), respectively.

A clear reduction plateau is not observed with added $\mathrm{Me}_{3} \mathrm{NSO}_{3}$ or $\mathrm{Et}_{3} \mathrm{NSO}_{3}$. Nevertheless, insertion of $\mathrm{Li}^{+}$is observed at lower potential upon addition of $1.0 \%$ or $2.0 \% \mathrm{Me}_{3} \mathrm{NSO}_{3}$ (Figure 3b). All three concentrations of $\mathrm{Et}_{3} \mathrm{NSO}_{3}(0.5 \%, 1.0 \%$, and $2.0 \%)$ afford intercalation of $\mathrm{Li}^{+}$into graphite reaching its full capacity at $0.005 \mathrm{~V}$ vs. $\mathrm{Li} / \mathrm{Li}^{+}$(Figure 3c). Upon passivation of graphite, excellent coulombic efficiency is observed, $92.9 \%$ and $93.5 \%$ with $1.0 \%$ and $2.0 \%$ added
$\mathrm{Me}_{3} \mathrm{NSO}_{3}$, respectively, and $93.4 \%, 93.7 \%$, and $93.5 \%$ with $0.5 \%$, $1.0 \%$, and $2.0 \%$ added $\mathrm{Et}_{3} \mathrm{NSO}_{3}$.

Since incorporation of added $\mathrm{PyrSO}_{3}, \mathrm{Me}_{3} \mathrm{NSO}_{3}$, or $\mathrm{Et}_{3} \mathrm{NSO}_{3}$ affords reversible cycling of graphite electrodes with $\mathrm{PC}$ based electrolytes, electrochemical cycling with graphite $/ \mathrm{LiNi}_{0.5} \mathrm{Mn}_{1.5} \mathrm{O}_{4}$ cells has been further investigated, as described below.

Surface analysis by XPS.-Graphite electrodes cycled once at the $\mathrm{C} / 20$ rate in half-cells at $25^{\circ} \mathrm{C}$ (Figure 3 ) have been analyzed with XPS analysis to develop a better understanding of the role of the additive in SEI formation on the graphite anode. The graphite electrodes have been analyzed in the delithiated state. Relative atomic concentration of selected elements present at the surface of the graphite electrodes is displayed in Table I and the C $1 \mathrm{~s}, \mathrm{~S} 2 \mathrm{p}$, and $\mathrm{N} 1 \mathrm{~s}$ element spectra are provided in Figures 4, 5, and 6, respectively.
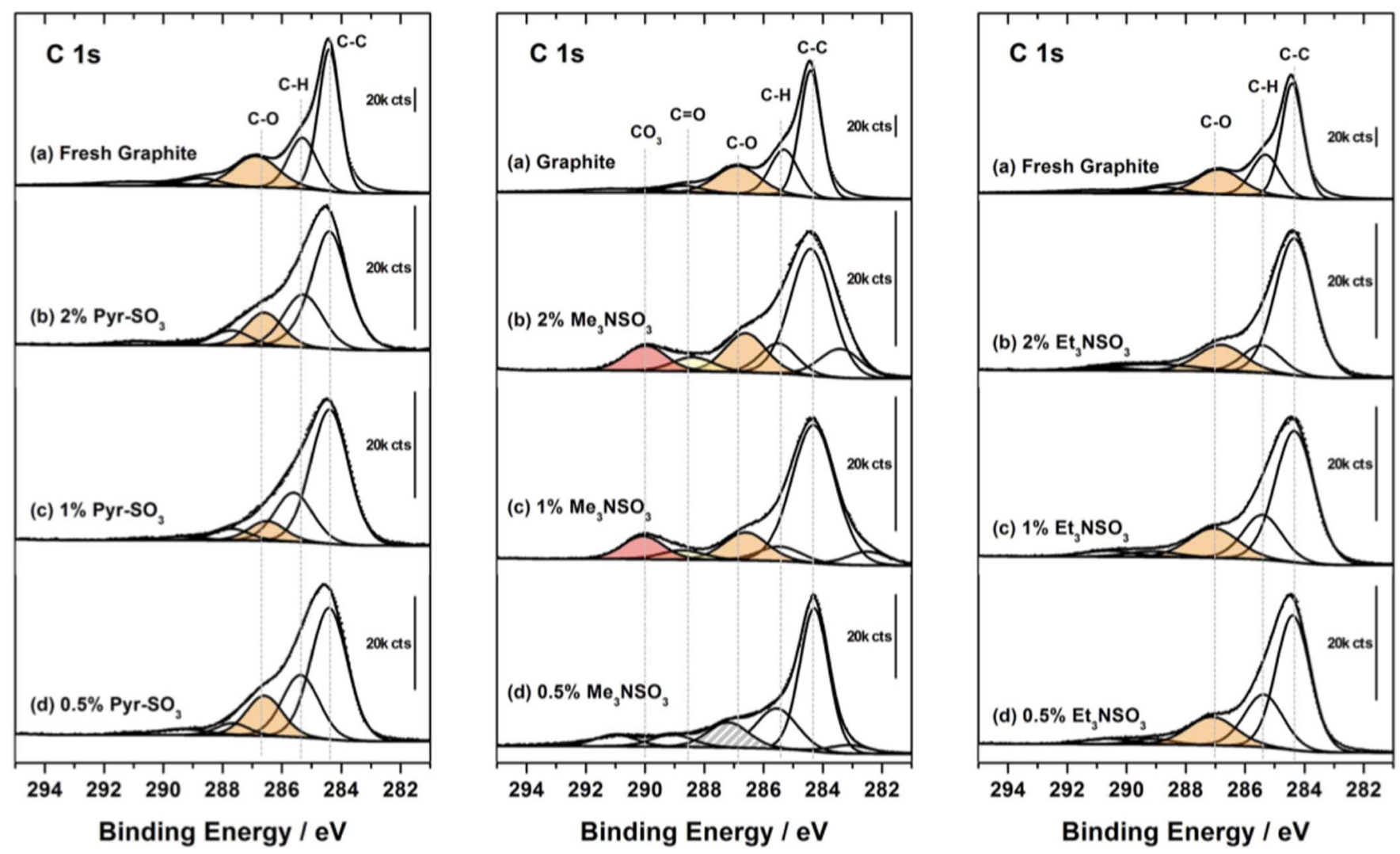

Figure 4. $\mathrm{C} 1 \mathrm{~s}$ core spectra of the (a) fresh graphite and (b, c, d) graphite electrodes after one cycle in graphite/Li half-cells at $25^{\circ} \mathrm{C}$ in the $\mathrm{PC} / \mathrm{EMC}(1 / 1 \mathrm{vol}$.) 1 $\mathrm{M} \mathrm{LiPF}_{6}$ electrolyte comprising (on the right) the $\mathrm{PyrSO}_{3}$ additive at concentrations of (b) $2.0 \%$ (wt), (c) $1.0 \%$ (wt), and (d) $0.5 \%$ (wt), (on the center) $\mathrm{Me}_{3} \mathrm{NSO}_{3}$ at concentrations of (b) $2.0 \%$ (wt) and (c) $1.0 \%$ (wt); (on the right) $\mathrm{Et}_{3} \mathrm{NSO}_{3}$ at concentrations of (b) $2.0 \%$ (wt) and (c) $1.0 \%$ (wt), and (d) $0.5 \%$ (wt). 

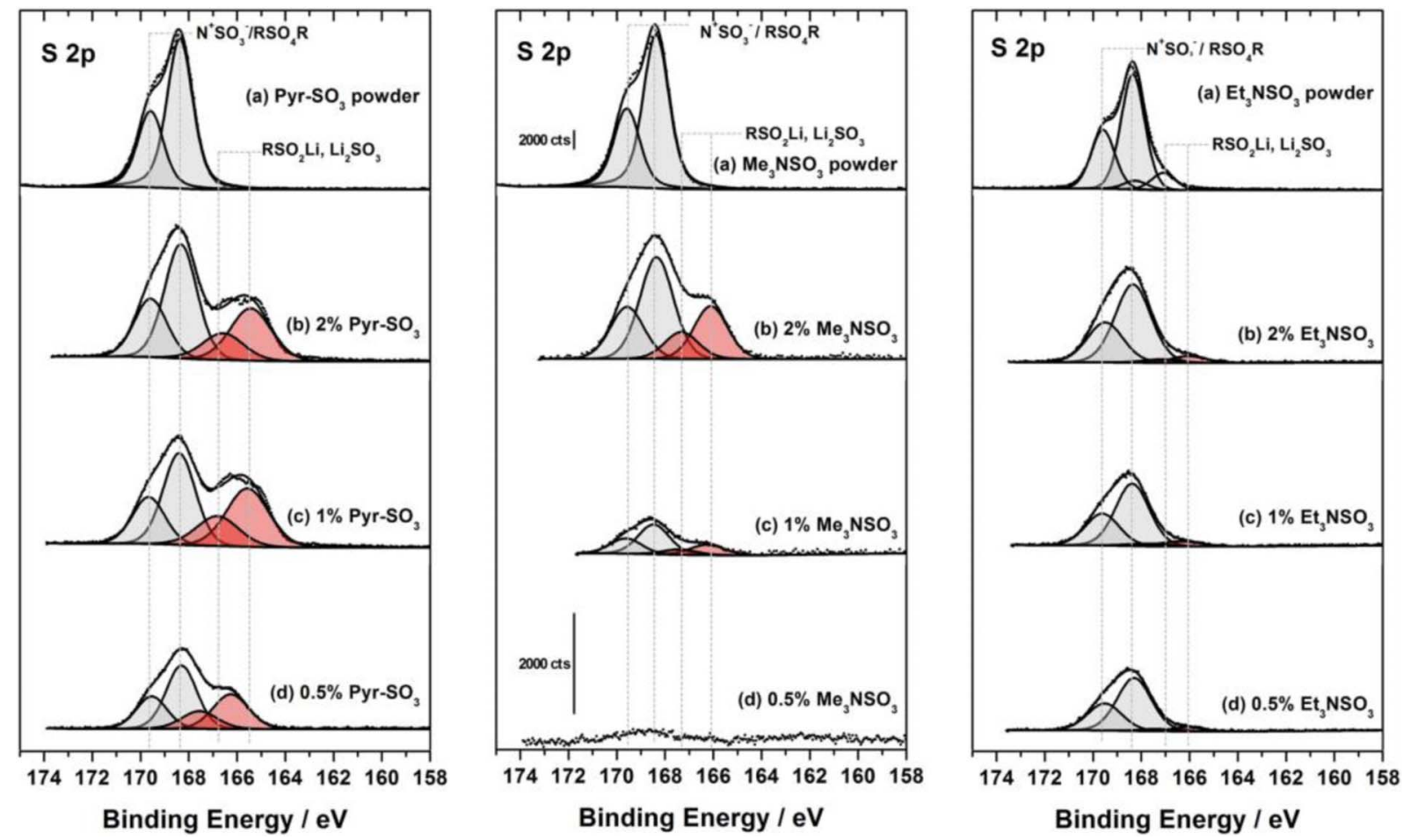

Figure 5. S 2p core spectra of the (a) $\mathrm{PyrSO}_{3}, \mathrm{Me}_{3} \mathrm{NSO}_{3}, \mathrm{Et}_{3} \mathrm{NSO}_{3}$ powders and graphite electrodes after one cycle in graphite/Li half-cells at $25^{\circ} \mathrm{C}$ in the PC/EMC (1/1 vol.) $1 \mathrm{M} \mathrm{LiPF}_{6}$ electrolyte comprising (on the right) the $\mathrm{PyrSO}_{3}$ additive at concentrations of (b) $2.0 \%$ (wt), (c) $1.0 \%$ (wt), and (d) $0.5 \%$ (wt), (on the center) $\mathrm{Me}_{3} \mathrm{NSO}_{3}$ at concentrations of (b) $2.0 \%$ (wt) and (c) $1.0 \%$ (wt); (on the right) $\mathrm{Et}_{3} \mathrm{NSO}_{3}$ at concentrations of (b) $2.0 \%$ (wt) and (c) $1.0 \%$ (wt), and (d) $0.5 \%(\mathrm{wt})$.

The fresh graphite electrode contains a high concentration of $\mathrm{C}$ from the graphite anodes and a low concentration of $\mathrm{O}$ from the $\mathrm{CMC} / \mathrm{SBR}$ binder and surface contamination of the graphite. All of the graphite electrodes cycled with electrolyte containing added $\mathrm{PyrSO}_{3}$ have similar concentrations of $\mathrm{F}, \mathrm{Li}, \mathrm{N}$, and $\mathrm{P}$. On the contrary, small variations in the concentrations of $\mathrm{C}, \mathrm{O}$, and $\mathrm{S}$ are observed for the electrodes cycled with electrolyte containing $2 \%, 1 \%$, and $0.5 \%$ $\mathrm{PyrSO}_{3}$. As the additive concentration increases, the concentration of $\mathrm{C}$ is decreased and the concentration of $\mathrm{O}$ and $\mathrm{S}$ are increased. This suggests that the decomposition products of $\mathrm{PyrSO}_{3}$ are incorporated into the SEI on the graphite anode. The graphite electrodes cycled with added $\mathrm{Me}_{3} \mathrm{NSO}_{3}$ or $\mathrm{Et}_{3} \mathrm{NSO}_{3}$ have variable concentrations of $\mathrm{C}$, $\mathrm{F}$, and $\mathrm{O}$ as a function of additive concentration. However, the presence of S along with the reversible cycling of the PC based electrolyte suggests that incorporation of the $\mathrm{SO}_{3}$ additives alter the structure of the SEI on the graphite electrodes.

The $\mathrm{C}$ 1s spectra of the graphitic anodes cycled with electrolyte containing $2.0 \%, 1.0 \%$, and $0.5 \%$ of added $\mathrm{SO}_{3}$ complex are presented in Figure 4, along with the fresh graphite electrode. For the composite graphite electrode (4a), characteristic peaks of C-C $(284.3 \mathrm{eV}), \mathrm{C}-\mathrm{H}$ $(285.6 \mathrm{eV})$, and $\mathrm{C}-\mathrm{O}(286.5 \mathrm{eV})$ are observed and are dominated by the C-C peak. ${ }^{27,28}$ Similar C $1 \mathrm{~s}$ peaks are observed at $284.3 \mathrm{eV}$ (C-C), $285.6 \mathrm{eV}(\mathrm{C}-\mathrm{H})$, and $286.5 \mathrm{eV}$ (C-O), with comparable intensities for graphite electrodes cycled with electrolyte containing all three concentrations of added $\mathrm{PyrSO}_{3}$ (Figures $4 \mathrm{~b}, 4 \mathrm{c}$, and $4 \mathrm{~d}$, on the left). Interestingly, there are no peaks observed at $290 \mathrm{eV}$ characteristic of $\mathrm{Li}_{2} \mathrm{CO}_{3}$ or lithium alkyl carbonates form carbonate solvent reduction observed for any of the graphite electrodes cycled with $\mathrm{PyrSO}_{3}{ }^{28}$ Thus, additive decomposition appears to suppress $\mathrm{PC} / \mathrm{EMC}$ reduction and allows reversible cycling of graphite, in a PC-based electrolyte.

Similar trends are observed for the $\mathrm{C} 1 \mathrm{~s}$ spectra of electrodes cycled with electrolytes containing added $\mathrm{Me}_{3} \mathrm{NSO}_{3}$ or $\mathrm{Et}_{3} \mathrm{NSO}_{3}$. The $\mathrm{C} 1 \mathrm{~s}$ spectrum of graphite cycled in $0.5 \% \mathrm{Me}_{3} \mathrm{NSO}_{3}$ is very similar to the one of fresh graphite $(4, a$ and $d)$, despite continuous electrolyte reduction on the anode during charging suggesting that the generation of soluble non-passivating reduction products are removed during electrode rinsing. When reversible cycling of graphite is observed at concentrations of $2.0 \%$ (Figure $4 \mathrm{~b}$ ) or $1.0 \% \mathrm{Me}_{3} \mathrm{NSO}_{3}$ (Figure $4 \mathrm{c}$ ), the $\mathrm{C} 1 \mathrm{~s}$ spectra of the cycled electrodes contain low concentrations of peaks characteristic of $\mathrm{CO}_{3}$ at $290 \mathrm{eV}$ (Figures 4b and 4c) consistent with the presence of low concentrations of lithium alkyl carbonates or $\mathrm{Li}_{2} \mathrm{CO}_{3}$ incorporated into the SEI. The $\mathrm{C} 1 \mathrm{~s}$ spectra of the anodes cycled with electrolyte containing added $\mathrm{Et}_{3} \mathrm{NSO}_{3}$ are very similar to those observed for the electrodes cycled with electrolytes containing $\mathrm{PyrSO}_{3}$.

For all three additives, $\mathrm{O} 1 \mathrm{~s}$ spectra of the graphite electrodes show a broad peak of oxygenated species in the $536 \mathrm{eV}-530 \mathrm{eV}$ binding energy range, as well as a predominant peak of $\mathrm{LiF}(685 \mathrm{eV})$ in the three F 1s spectra (not shown here).

All the $\mathrm{S} 2 \mathrm{p}$ spectra of the graphite electrodes cycled in the $\mathrm{PyrSO}_{3}$ based electrolytes exhibit the main doublet of $\mathrm{N}^{+} \mathrm{SO}_{3}{ }^{-} / \mathrm{RSO}_{3} \mathrm{Li}$ at $168.3 \mathrm{eV}$ (Figure 5, on the left), consistent with the generation of lithium alkyl sulfonates, as previously reported for electrolytes containing PS. ${ }^{19,20}$ Furthermore, intensities of the $\mathrm{S} 2 \mathrm{p}$ spectra increase with increasing concentration of the $\mathrm{PyrSO}_{3}$ additive in the electrolyte. The S 2 p spectra also include an $\mathrm{S} 2 \mathrm{p}$ doublet of $\mathrm{RSO}_{2} \mathrm{Li}$ and $\mathrm{Li}_{2} \mathrm{SO}_{3}$ at $166.2 \mathrm{eV}$, which results from the further reduction of the $\mathrm{SO}_{3}$ complexes on the lithiated graphite surface. ${ }^{29,30}$ Similar trends are observed for the $\mathrm{S} 2 \mathrm{p}$ spectra of graphite electrodes cycled with electrolyte containing added $\mathrm{Me}_{3} \mathrm{NSO}_{3}$ and $\mathrm{Et}_{3} \mathrm{NSO}_{3}$. The S $2 \mathrm{p}$ peak intensity increases for the graphite electrodes cycled with either $\mathrm{Me}_{3} \mathrm{NSO}_{3}$ or $\mathrm{Et}_{3} \mathrm{NSO}_{3}$ as the additive concentration in the electrolyte increases (Figure 5). Although at a low concentration of $\mathrm{Me}_{3} \mathrm{NSO}_{3}$ $(0.5 \%)$ continuous electrolyte reduction is observed and no $\mathrm{S}$ is observed on the surface, consistent with the importance of the $\mathrm{SO}_{3}$ reduction products in the formation of a stable SEI.

The reactivity of the $\mathrm{PyrSO}_{3}$ complex at low potential is also supported by the $\mathrm{N} 1 \mathrm{~s}$ core spectra of graphite electrodes depicted in Figure 6. Distinct N 1s peaks are observed for the graphite electrodes cycled with the $\mathrm{PyrSO}_{3}$-based electrolyte, consistent with the 


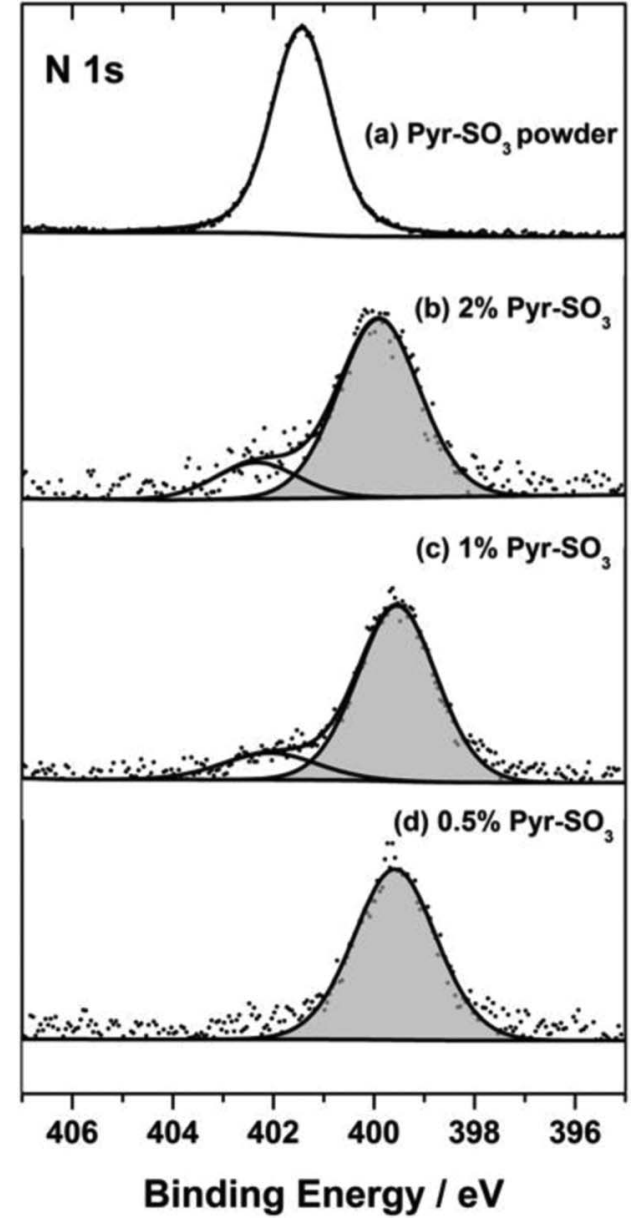

Figure 6. $\mathrm{N}$ 1s core spectra of the (a) $\mathrm{PyrSO}_{3}$ powder and graphite electrodes after one cycle in graphite/Li half-cells at $25^{\circ} \mathrm{C}$ in the PC/EMC (1/1 vol.) $1 \mathrm{M} \mathrm{LiPF}_{6}$ electrolyte comprising the $\mathrm{PyrSO}_{3}$ additive at concentrations of (b) $2.0 \%(w t),(c) 1.0 \%(w t)$, and (d) $0.5 \%(w t)$.

highest reactivity of the $\mathrm{PyrSO}_{3}$ additives in graphite half-cells (Figure 6). While a single pyridine peak is observed at $401 \mathrm{eV}$ for the pure additive powder, the cycled electrodes contain a new peak at $399 \mathrm{eV}$ consistent with the presence of pyridinium species. ${ }^{31,32}$ The $\mathrm{N}$ 1s peak intensity is lower for all the graphite electrodes cycled with $\mathrm{Me}_{3} \mathrm{NSO}_{3}$ or $\mathrm{Et}_{3} \mathrm{NSO}_{3}$, which may result from lower reactivity or higher solubility of the amine reduction products compared to the pyridine reduction products.

Incorporation of $\mathrm{SO}_{3}$ complexes into $\mathrm{PC}$ based electrolytes results in passivation of the graphite surface, which allows reversible cycling. The XPS analysis suggests that the passivating surface layers are composed of sulfur containing species and the predominant decomposition product of $\mathrm{LiPF}_{6}(\mathrm{LiF})$. The $\mathrm{C}$ 1s core spectra of electrodes suggest that the $\mathrm{S}$ containing passivation film significantly reduces carbonate solvent reduction on the graphite surface.

$\mathrm{LiNi}_{0.5} \mathrm{Mn}_{1.5} \mathrm{O}_{4} /$ Graphite cells in PC-based electrolytes.Cycling performance.-While incorporation of $\mathrm{SO}_{3}$ complexes into PC based electrolytes for lithium ion batteries clearly leads to modification of the graphite SEI and improved cycling performance, there is also significant interest in the use of high voltage cathode materials including, $\mathrm{LiNi}_{0.5} \mathrm{Mn}_{1.5} \mathrm{O}_{4}$. Thus, the incorporation of $\mathrm{SO}_{3}$ complexes into graphite/high voltage spinel cells $\left(\mathrm{Gr} / \mathrm{LiNi}_{0.5} \mathrm{Mn}_{1.5} \mathrm{O}_{4}\right)$ has been conducted to probe oxidation of the additives on the cathode to generate cathode passivation films. The cycle voltage profiles, capacity retention and coulombic efficiency for PC elec-
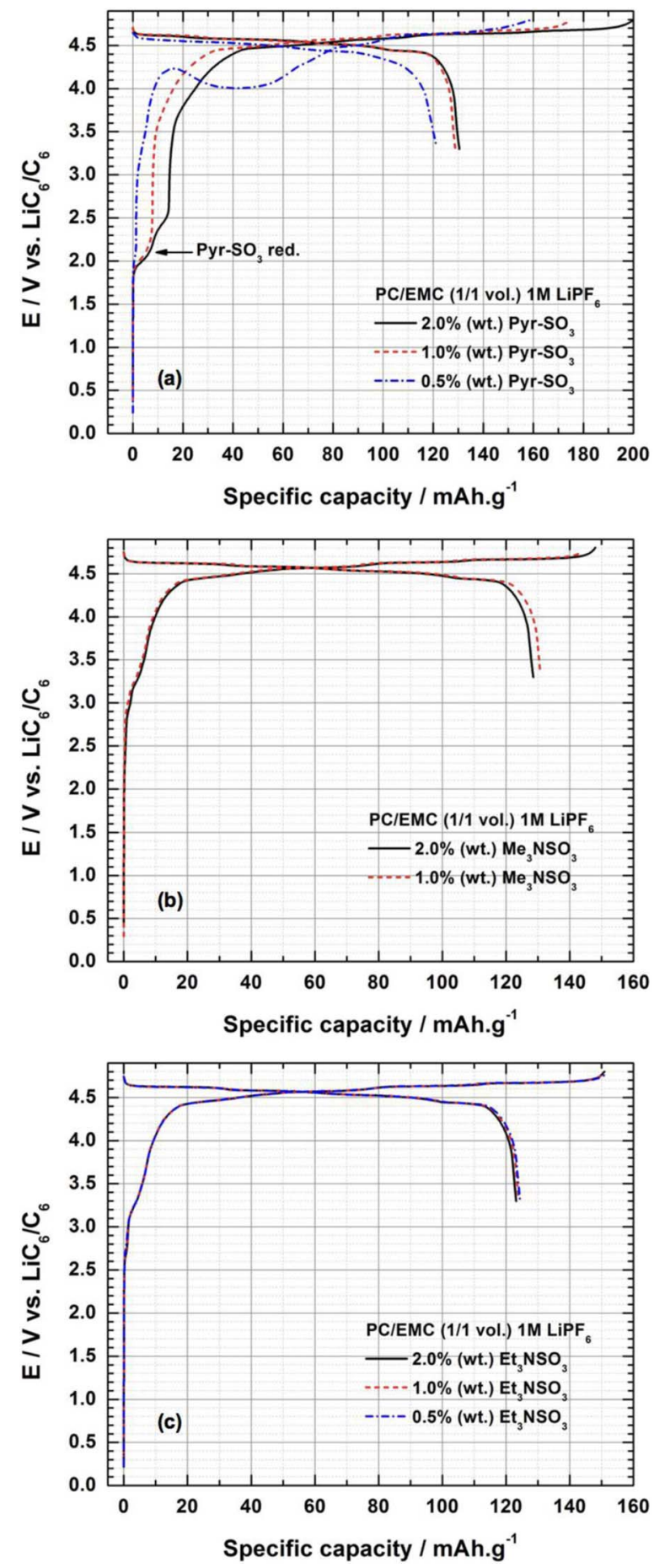

Figure 7. First cycle voltage profile of $\mathrm{LiNi}_{0.5} \mathrm{Mn}_{1.5} \mathrm{O}_{4} / \mathrm{Gr}$ cells at $25^{\circ} \mathrm{C}(\mathrm{C} / 20$ D/20, cutoff limits: $4.80 \mathrm{~V}-3.30 \mathrm{~V}$ vs. $\left.\mathrm{LiC}_{6} / \mathrm{C}_{6}\right)$ using PC/EMC (1/1 vol.) $\mathrm{LiPF}_{6} 1 \mathrm{M}$ as the baseline electrolyte with the (a) $\mathrm{PyrSO}_{3}$, (b) $\mathrm{Me}_{3} \mathrm{NSO}_{3}$, and (c) $\mathrm{Et}_{3} \mathrm{NSO}_{3}$ additives (concentrations of 2.0\%, 1.0\%, and 0.5\% (wt)).

trolytes with added $\mathrm{PyrSO}_{3}, \mathrm{Me}_{3} \mathrm{NSO}_{3}$ and $\mathrm{Et}_{3} \mathrm{NSO}_{3}$ are provided in Figure 7 and Figure 8.

As seen from Figure $7 \mathrm{a}, \mathrm{PyrSO}_{3}$ reduction is observed on graphite between $2.0 \mathrm{~V}-2.5 \mathrm{~V}$ vs. $\mathrm{LiC}_{6} / \mathrm{C}_{6}$, as discussed above for $\mathrm{Gr} / \mathrm{Li}$ cells (Figure 3). A reasonable discharge capacity of ca. $130 \mathrm{mAh} \cdot \mathrm{g}^{-1}$ is observed with either 1.0 or $2.0 \%$ of added $\mathrm{PyrSO}_{3}$. The first cycle coulombic efficiencies are somewhat low at $64.8 \%$ and $73.4 \%$, respectively. The low values of efficiency are likely due to a combination of electrolyte reduction on the anode to form the SEI and electrolyte 

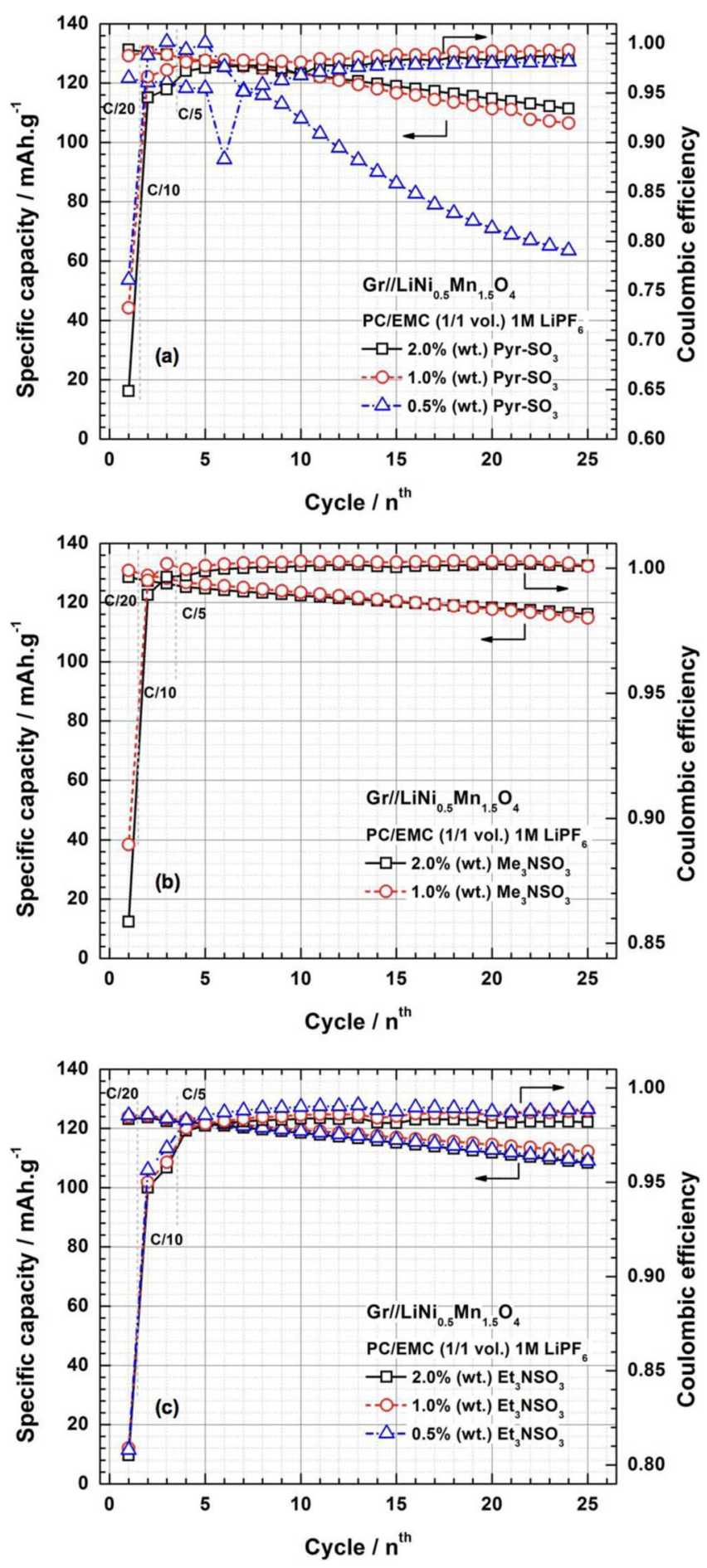

Figure 8. Cycling retention of $\mathrm{LiNi}_{0.5} \mathrm{Mn}_{1.5} \mathrm{O}_{4} / \mathrm{Graphite}$ cells $(\mathrm{C} / 5 \mathrm{D} / 5$, cutoff potentials at $25^{\circ} \mathrm{C}: 4.80 \mathrm{~V}-3.30 \mathrm{~V}$ vs. $\left.\mathrm{LiC}_{6} / \mathrm{C}_{6}\right)$ using the $\mathrm{PC} / \mathrm{EMC}(1 / 1 \mathrm{vol}$.) $1 \mathrm{M} \mathrm{LiPF}_{6}$ electrolyte, which contains the (a) $\mathrm{Me}_{3} \mathrm{NSO}_{3}$ and (b) $\mathrm{Et}_{3} \mathrm{NSO}_{3}$ additives.

oxidation on the cathode surface at high voltage. ${ }^{33,34}$ At lower concentrations of $\mathrm{PyrSO}_{3}(0.5 \%)$, the additive does not afford good first cycle performance for $\mathrm{LiNi}_{0.5} \mathrm{Mn}_{1.5} \mathrm{O}_{4} / \mathrm{Gr}$ cells. The first charge voltage profile contains a drop in potential from $4.3 \mathrm{~V}$ to $3.9 \mathrm{~V}$ consistent with decomposition of the electrolyte and cycling instability as discussed below (Figure 7a).

The voltage profiles during the first cycle at $\mathrm{C} / 20$ for cells containing electrolyte with added $\mathrm{Me}_{3} \mathrm{NSO}_{3}$ or $\mathrm{Et}_{3} \mathrm{NSO}_{3}$ are presented in Figures $7 \mathrm{~b}$ and $7 \mathrm{c}$, respectively. The profiles have a similar shape, with comparable charge capacity, which is independent of the additive concentration (ca. $150 \mathrm{mAh} . \mathrm{g}^{-1}$ ). A plateau is observed at $3.25 \mathrm{~V}$ vs. $\mathrm{LiC}_{6} / \mathrm{C}_{6}$ attributed to the reduction of $\mathrm{Me}_{3} \mathrm{NSO}_{3}$ or $\mathrm{Et}_{3} \mathrm{NSO}_{3}$ on the graphite electrode (Figures $7 \mathrm{~b}$ and $7 \mathrm{c}$ ). However, the discharge capacities, do not depend on additive concentration but are slightly lower with added $\mathrm{Et}_{3} \mathrm{NSO}_{3}$ (ca. $123 \mathrm{mAh} . \mathrm{g}^{-1}$ ) compared to $\mathrm{Me}_{3} \mathrm{NSO}_{3}$ (ca. $130 \mathrm{mAh} . \mathrm{g}^{-1}$ ). The difference in behavior is not observed for $\mathrm{Gr} / \mathrm{Li}$ cells suggesting the different amine $\mathrm{SO}_{3}$ complexes have different reactivity toward the high voltage spinel.

Cycling performance at $25^{\circ} \mathrm{C}$ for the first 25 cycles of $\mathrm{LiNi}_{0.5} \mathrm{Mn}_{1.5} \mathrm{O}_{4} / \mathrm{Gr}$ cells with $\mathrm{PC}$ based electrolytes with added $\mathrm{SO}_{3}$ complexes is presented in Figure 8. Cycling performance of full cells with added $\mathrm{PyrSO}_{3}$ is displayed in Figure 8a. Good capacity retention and efficiency are observed at higher concentrations of $\mathrm{PyrSO}_{3}(2.0 \%$ and $1.0 \%$ ) with $85 \%$ and $82 \%$ capacity retention after 25 cycles and over $99 \%$ coulombic efficiency for the final 10 cycles. However, significant capacity loss $(47.7 \%)$ is obtained for cells containing $0.5 \%$ of $\mathrm{PyrSO}_{3}$. The poor cycling performance is likely due to poor passivation of graphite (Figure 7a).

Cells containing electrolyte with $1 \%$ or $2 \%$ of added $\mathrm{Me}_{3} \mathrm{NSO}_{3}$ have better capacity retention, $90 \%$ and $88 \%$, respectively (Figure 8 b). The coulombic efficiency is also found to be excellent, $99.9 \%$. Cells containing electrolyte with added $\mathrm{Et}_{3} \mathrm{NSO}_{3}$ also show good capacity retention (88-91\%) and high efficiency (>98\%) for all additive concentrations. Thus, superior cycleability of cells containing either the $\mathrm{Me}_{3} \mathrm{NSO}_{3}$ complex or the $\mathrm{Et}_{3} \mathrm{NSO}_{3}$ complex is observed in high voltage $\mathrm{LiNi}_{0.5} \mathrm{Mn}_{1.5} \mathrm{O}_{4} / \mathrm{Gr}$ cells, in agreement with that observed in graphite/Li cells. Ex-situ surface analysis of the electrodes has been conducted in order to develop a better understanding of the source of the performance enhancement of added $\mathrm{SO}_{3}$ complexes.

Surface analysis by XPS. - $\mathrm{LiNi}_{0.5} \mathrm{Mn}_{1.5} \mathrm{O}_{4}$ cathodes. - Surface analysis of the cathodes extracted from graphite/ $/ \mathrm{LiNi}_{0.5} \mathrm{Mn}_{1.5} \mathrm{O}_{4}$ cells after 25 cycles at $25^{\circ} \mathrm{C}$ has been conducted by XPS. The $\mathrm{LiNi}_{0.5} \mathrm{Mn}_{1.5} \mathrm{O}_{4}$ electrodes are analyzed in the lithiated state ( $0 \%$ SOC). Relative atomic concentrations present on the surface of the high voltage spinel electrodes are provided in Table II.

The fresh LNMO electrode shows a high concentration of $\mathrm{C}, \mathrm{O}$, $\mathrm{Mn}$, and $\mathrm{F}$ from the oxide particles and the PVdF binder. For the cathodes cycled with electrolyte containing added $\mathrm{PyrSO}_{3}$, two types of behaviors are observed depending on the additive concentration, which relates to the cycling performance discussed above (Figure 8). For the cathodes cycled with electrolyte containing 1-2\% $\mathrm{PyrSO}_{3}$, similar concentrations of elements are found, while differences are observed with $0.5 \% \mathrm{PyrSO}_{3}$. The relative concentration of $\mathrm{C}$ is decreased and the concentration of $\mathrm{O}$ is increased consistent with lower concentrations of $\mathrm{PyrSO}_{3}$ and less passivation of the cathode surface. The thinner surface films with low concentrations of $\mathrm{PyrSO}_{3}$ correlate with the poor cycling performance. The cathodes cycled with electrolyte containing added $\mathrm{Me}_{3} \mathrm{NSO}_{3}$ or $\mathrm{Et}_{3} \mathrm{NSO}_{3}$ have very similar element concentrations for all concentrations investigated. Cells with all concentrations of added $\mathrm{Me}_{3} \mathrm{NSO}_{3}$ or $\mathrm{Et}_{3} \mathrm{NSO}_{3}$ have good cycling performance that the thin surface films correlate with good cycling performance (Figure 8). The results suggest that the presence of the aromatic pyridyl group may lead to higher reactivity of the cathode surface and thicker surface films, but the presence of the amines leads to thinner but more effective passivation layers on the cathode.

The $\mathrm{O} 1 \mathrm{~s}$ spectra of cathodes cycled with electrolyte containing $\mathrm{PyrSO}_{3}, \mathrm{Me}_{3} \mathrm{NSO}_{3}$, and $\mathrm{Et}_{3} \mathrm{NSO}_{3}$ are depicted in Figure 9. The cathodes cycled with the $\mathrm{PyrSO}_{3}$ additive have a weak O-M peak at 529 $\mathrm{eV}$ consistent with the presence of a thick cathode surface film covering the metal oxide particles. ${ }^{35,36}$ The $\mathrm{O} 1 \mathrm{~s}$ spectrum is dominated by a broad peak centered at $532 \mathrm{eV}$ characteristic of $\mathrm{C}-\mathrm{O}, \mathrm{C}=\mathrm{O}$, and $\mathrm{S}-\mathrm{O}$ containing species from the reaction of the electrolyte. The cathodes cycled with $\mathrm{Me}_{3} \mathrm{NSO}_{3}$ and $\mathrm{Et}_{3} \mathrm{NSO}_{3}$ additives have much stronger O-M peaks at $529 \mathrm{eV}$ and a weaker broad peak associated with electrolyte decomposition at $532 \mathrm{eV}$ consistent with a thinner cathode surface film. Interestingly, the intensity of the M-O peak is in agreement with the elemental concentration data, suggesting that the 
Table II. Relative atomic percentage (\%) of selected elements at the surface of the $\mathrm{LiNi}_{0.5} \mathrm{Mn}_{1.5} \mathrm{O}_{4}$ electrodes after cycling in $\mathrm{LiNi} \mathrm{g}_{0.5} \mathrm{Mn}_{1.5} \mathrm{O}_{4} / \mathrm{Gr}$ cells at $25^{\circ} \mathrm{C}$.

\begin{tabular}{|c|c|c|c|c|c|c|c|c|}
\hline \multicolumn{2}{|c|}{ Additive concentration } & $\mathrm{C} 1 \mathrm{~s}$ & F $1 \mathrm{~s}$ & O 1s & $\operatorname{Mn} 2 p$ & S $2 p$ & $\mathrm{~N} 1 \mathrm{~s}$ & P $2 p$ \\
\hline \multicolumn{2}{|c|}{ Fresh LNMO } & 39 & 15 & 9 & 37 & - & - & - \\
\hline \multirow{3}{*}{$\mathrm{PyrSO}_{3}$} & $2.0 \%(w \mathrm{t})$ & 39 & 27 & 22 & 1 & 3 & 4 & 4 \\
\hline & $1.0 \%(\mathrm{wt})$ & 40 & 25 & 22 & 1 & 2 & 5 & 5 \\
\hline & $0.5 \%(\mathrm{wt})$ & 28 & 27 & 30 & 2 & 0 & 1 & 12 \\
\hline \multirow[t]{2}{*}{$\mathrm{Me}_{3} \mathrm{NSO}_{3}$} & $2.0 \%(\mathrm{wt})$ & 52 & 22 & 19 & 3 & 1 & 1 & 2 \\
\hline & $1.0 \%(\mathrm{wt})$ & 49 & 22 & 20 & 3 & 1 & 1 & 3 \\
\hline \multirow[t]{3}{*}{$\mathrm{Et}_{3} \mathrm{NSO}_{3}$} & $2.0 \%(\mathrm{wt})$ & 50 & 23 & 20 & 3 & 1 & 1 & 3 \\
\hline & $1.0 \%(\mathrm{wt})$ & 48 & 22 & 22 & 5 & 1 & 1 & 3 \\
\hline & $0.5 \%(w t)$ & 49 & 22 & 21 & 3 & 1 & 1 & 3 \\
\hline
\end{tabular}

cathode surface film thickness is largely independent of the concentration of added $\mathrm{Me}_{3} \mathrm{NSO}_{3}$ or $\mathrm{Et}_{3} \mathrm{NSO}_{3}$.

C 1s spectra of the $\mathrm{LiNi}_{0.5} \mathrm{Mn}_{1.5} \mathrm{O}_{4}$ cathodes are presented in Figure 10. The fresh (uncycled) cathode (Figure 10a) contains peaks characteristic of conductive carbon $(284.3 \mathrm{eV})$ and the PVdF binder $\left(-\mathrm{CH}_{2}-\right.$ at $286.5 \mathrm{eV}$ and $-\mathrm{CF}_{2}-$ at $\left.290.7 \mathrm{eV}\right){ }^{36,37}$ The cathodes cycled in the $\mathrm{PyrSO}_{3}$-containing electrolytes reveal significant quantities of electrolyte decomposition on the surface. Upon incorporation of $1-2 \% \mathrm{PyrSO}_{3}$ new peaks characteristic of $\mathrm{C}-\mathrm{H}(286.5 \mathrm{eV}), \mathrm{C}-\mathrm{O}(286.5$ $\mathrm{eV})$, and $\mathrm{CO}_{3}(290 \mathrm{eV})$ are observed, while the $\mathrm{C}-\mathrm{C}$ peak at $284.3 \mathrm{eV}$ is diminished and the $\mathrm{CF}_{2}(\mathrm{PVdF})$ peak at $290.7 \mathrm{eV}$ is no longer observable. The electrode cycled with $0.5 \% \mathrm{PyrSO}_{3}$ has only $\mathrm{C}-\mathrm{C}$ $(284.3 \mathrm{eV}), \mathrm{CH}_{2}(285.6 \mathrm{eV}), \mathrm{C}=\mathrm{O}(287.7 \mathrm{eV})$ and $\mathrm{CO}_{3}(290 \mathrm{eV})$ observable. ${ }^{35,36,38}$ The small contribution of the $\mathrm{C}-\mathrm{C}$ peak and significant concentration of $\mathrm{C}-\mathrm{O}$ and $\mathrm{C}=\mathrm{O}$ peaks suggests a significant coverage of the cathode material by decomposition products of the electrolyte, consistent with the intensities of the $\mathrm{O}-\mathrm{M}$ peak in the $\mathrm{O}$ 1s spectra. The $\mathrm{LiNi}_{0.5} \mathrm{Mn}_{1.5} \mathrm{O}_{4}$ cathodes cycled with electrolyte containing either $\mathrm{Me}_{3} \mathrm{NSO}_{3}$ or $\mathrm{Et}_{3} \mathrm{NSO}_{3}$ are different that those cycled with $\mathrm{PyrSO}_{3}$. The C-C (284.3 eV), $\mathrm{CH}_{2}(286.5 \mathrm{eV})$ and $\mathrm{CF}_{2}(290.7$ $\mathrm{eV})$ peaks of the PVdF binder are weak, but visible, suggesting thinner passive layers. Nevertheless, the CEI of these cathodes contains the $\mathrm{C}-\mathrm{O}(286.5 \mathrm{eV}), \mathrm{C}=\mathrm{O}(287.7 \mathrm{eV})$, and $\mathrm{CO}_{3}(290 \mathrm{eV})$ functional groups coming from $\mathrm{PC}$ and EMC oxidation. As previously observed from the $\mathrm{O} 1 \mathrm{~s}$ spectra, the $\mathrm{C} 1 \mathrm{~s}$ spectra are very similar for all additive concentrations. The surface chemistry of the cathode surface layers does not depend on the additive concentration in the baseline electrolyte.

The $S 2 p$ spectra of the cathodes are depicted in Figure 11. For the cathodes cycled with $\mathrm{PyrSO}_{3}$ are dominated by the doublet of peaks characteristic of $\mathrm{N}^{+} \mathrm{SO}_{3}{ }^{-} / \mathrm{RSO}_{3} \mathrm{Li}$. An additional minor doublet of peaks characteristic of S-S species appears at $164 \mathrm{eV}^{39-41}$ The presence of $S$ on the surface suggests participation of the sulfonate in the CEI (Cathode Electrolyte Interface). When the concentration of
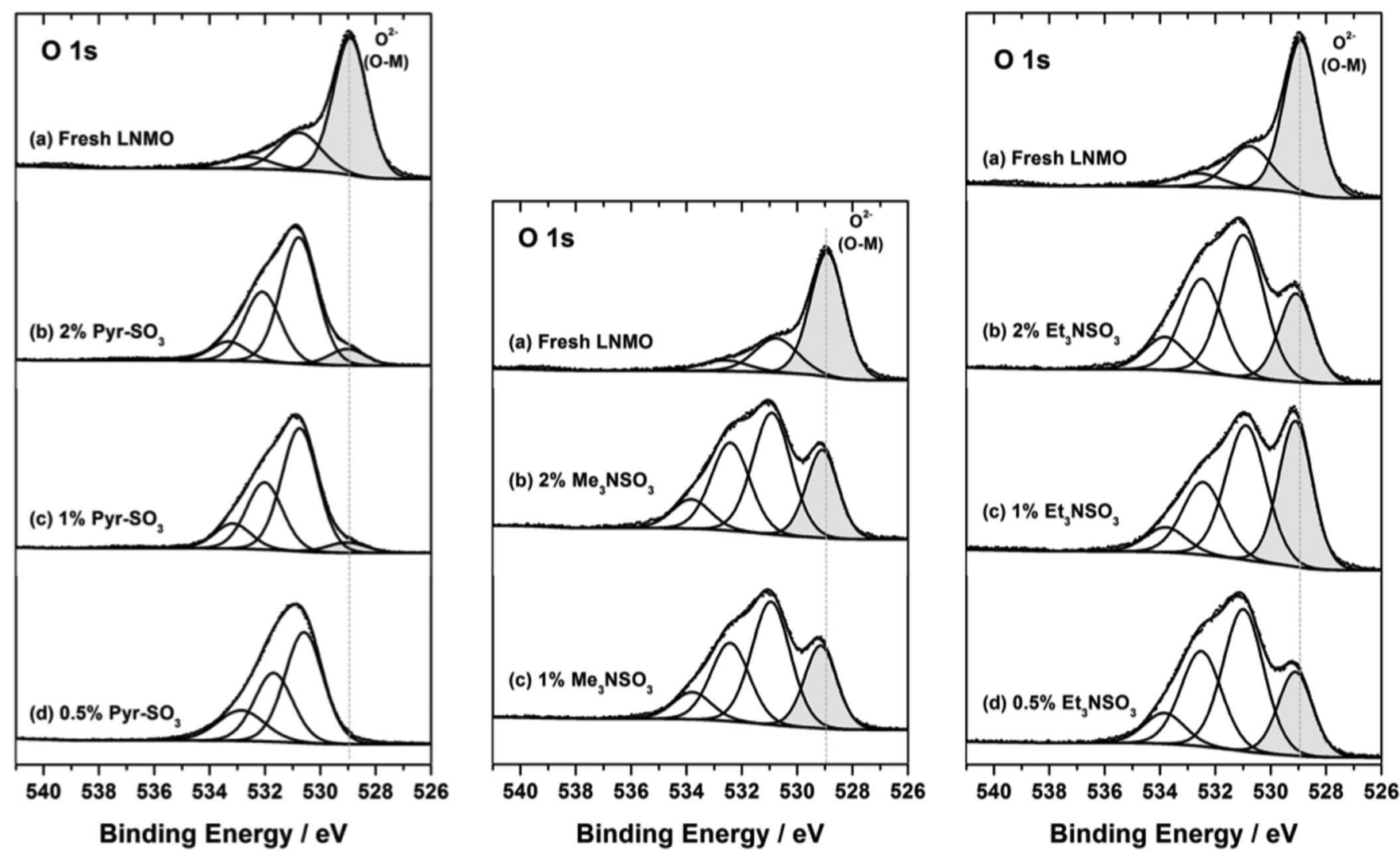

Figure 9. $\mathrm{O} 1 \mathrm{~s}$ core spectra of (a) the $\mathrm{LiNi}_{0.5} \mathrm{Mn}_{1.5} \mathrm{O}_{4}$ fresh electrode and $\mathrm{LiNi}_{05} \mathrm{Mn}_{15} \mathrm{O}_{4}$ cathodes cycled with graphite in the PC/EMC (1/1 vol.) $1 \mathrm{M} \mathrm{LiPF} 6$ electrolyte comprising (on the right) the $\mathrm{PyrSO}_{3}$ additive at concentrations of (b) $2.0 \%$ (wt), (c) $1.0 \%$ (wt), and (d) $0.5 \%$ (wt), (on the center) the Me $\mathrm{NSO}_{3}$ additive at concentrations of (b) $2.0 \%$ (wt), (c) $1.0 \%$ (wt), and (on the left) $\mathrm{Et}_{3} \mathrm{NSO}_{3}$ at concentrations of (b) $2.0 \%$ (wt), (c) $1.0 \%$ (wt), and (d) $0.5 \%$ (wt). 

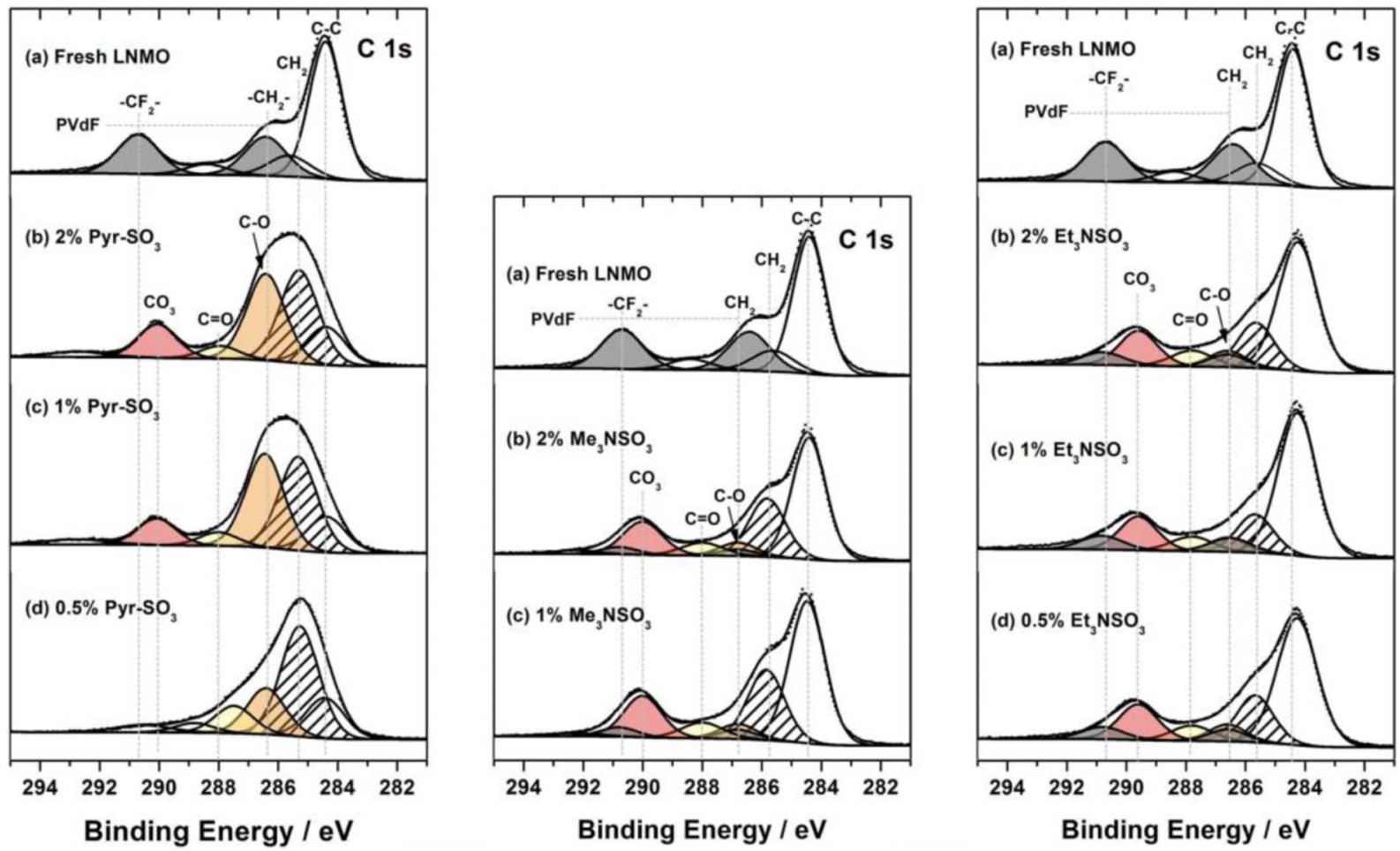

Figure 10. $\mathrm{C} 1 \mathrm{~s}$ core spectra of (a) the $\mathrm{LiNi}_{0.5} \mathrm{Mn}_{1.5} \mathrm{O}_{4}$ fresh electrode and $\mathrm{LiNi}_{0.5} \mathrm{Mn}_{1.5} \mathrm{O}_{4}$ cathodes cycled with graphite in the PC/EMC (1/1 vol.) $1 \mathrm{M} \mathrm{LiPF} 6$ electrolyte comprising (on the right) the $\mathrm{PyrSO}_{3}$ additive at concentrations of (b) $2.0 \%$ (wt), (c) $1.0 \%$ (wt), and (d) $0.5 \%$ (wt), (on the center) the $\mathrm{Me}_{3} \mathrm{NSO}_{3}$ additive at concentrations of (b) $2.0 \%$ (wt), (c) $1.0 \%$ (wt), and (on the left) $\mathrm{Et}_{3} \mathrm{NSO}_{3}$ at concentrations of (b) $2.0 \%$ (wt), (c) $1.0 \%$ (wt), and (d) $0.5 \%$ (wt).

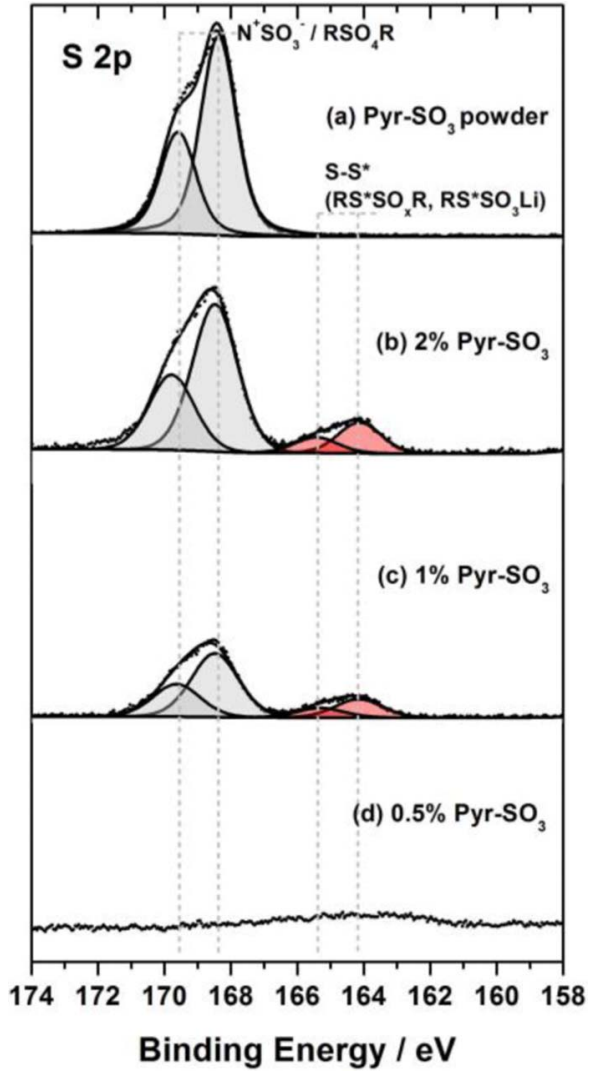

Figure 11. $\mathrm{S} 2 \mathrm{p}$ core spectra of (a) the $\mathrm{PyrSO}_{3}$ powder and $\mathrm{LiNi}_{0.5} \mathrm{Mn}_{1.5} \mathrm{O}_{4}$ cathodes cycled with graphite in the PC/EMC (1/1 vol.) $1 \mathrm{M} \mathrm{LiPF}_{6}$ electrolyte comprising the $\mathrm{PyrSO}_{3}$ additive at concentrations of (b) $2.0 \%$ (wt), (c) $1.0 \%$ (wt), and (d) $0.5 \%(w t)$.
$\mathrm{PyrSO}_{3}$ is reduced to $0.5 \%$, no sulfur is detected on the $\mathrm{LiNi}_{0.5} \mathrm{Mn}_{1.5} \mathrm{O}_{4}$ surface. The concentration of $\mathrm{S}$ on the surface of electrodes cycled with electrolyte containing either $\mathrm{Me}_{3} \mathrm{NSO}_{3}$ or $\mathrm{Et}_{3} \mathrm{NSO}_{3}$ is very low for all additive concentrations, consistent with thin cathode surface films as discussed above.

To conclude, two types of CEIs are observed on the $\mathrm{LiNi}_{0.5} \mathrm{Mn}_{1.5} \mathrm{O}_{4}$ cathode depending on the additive structure. For the $\mathrm{PyrSO}_{3}$ electrolytes, significant electrolyte decomposition is observed via the $\mathrm{O}$ $1 \mathrm{~s}$ and $\mathrm{C}$ 1s spectra. This results in the generation of a thick passive layer which contains S. Alternatively, incorporation of $\mathrm{Me}_{3} \mathrm{NSO}_{3}$ and $\mathrm{Et}_{3} \mathrm{NSO}_{3}$ additives results in a thin, but passivating CEI. Consequently, better cycling retention and higher coulombic efficiency are observed for PC/EMC electrolytes with added $\mathrm{Me}_{3} \mathrm{NSO}_{3}$ and $\mathrm{Et}_{3} \mathrm{NSO}_{3}$.

The graphite anodes extracted from graphite/ $/ \mathrm{LiNi}_{0.5} \mathrm{Mn}_{1.5} \mathrm{O}_{4}$ cells cycled with $\mathrm{PC}$ based electrolyte with added $\mathrm{SO}_{3}$ complexes were also analyzed by XPS. The surface species are relatively similar to those observed on the graphite electrodes extracted from Li/graphite cells and are not presented here.

\section{Conclusions}

An investigation of novel bifunctional additives $\mathrm{PyrSO}_{3}$, $\mathrm{Me}_{3} \mathrm{NSO}_{3}$ and $\mathrm{Et}_{3} \mathrm{NSO}_{3}$ has been conducted. In order to develop an understanding of the role of $\mathrm{SO}_{3}$ additives in anode SEI formation and stability, $\mathrm{PC}$ based electrolytes with and without added $\mathrm{SO}_{3}$ complexes have been conducted. Incorporation of any of the $\mathrm{SO}_{3}$ complexes, $\mathrm{PyrSO}_{3}, \mathrm{Me}_{3} \mathrm{NSO}_{3}$ and $\mathrm{Et}_{3} \mathrm{NSO}_{3}$, result in the generation of a stable SEI on the graphite electrodes allowing reversible cycling with high coulombic efficiency with the PC-based electrolyte. The $\mathrm{SO}_{3}$ complexes are reduced at low potential into sulfates and sulfites, as evidenced by XPS analysis, which results in an efficient passivation layer on the graphite. The compatibility of the $\mathrm{SO}_{3}$ additives with high voltage cathodes has also been probed. Excellent cycling performance of $\mathrm{LiNi}_{0.5} \mathrm{Mn}_{1.5} \mathrm{O}_{4} / \mathrm{Gr}$ cell has been obtained with the same PC-based electrolyte with added $\mathrm{Me}_{3} \mathrm{NSO}_{3}$ or $\mathrm{Et}_{3} \mathrm{NSO}_{3}$. 
Incorporation of $\mathrm{Me}_{3} \mathrm{NSO}_{3}$ and $\mathrm{Et}_{3} \mathrm{NSO}_{3}$ results in a thin but stable cathode passivation layer on the $\mathrm{LiNi}_{0.5} \mathrm{Mn}_{1.5} \mathrm{O}_{4}$ oxide particles resulting in good cyclability and coulombic efficiency.

\section{Acknowledgment}

The authors thank BASF SE Electrochemistry Research Network for financial support.

\section{References}

1. K. Xu, Chemical reviews, 114, 11503 (2014).

2. K. Xu, Chemical reviews, 104, 4303 (2004).

3. M. Nie and B. L. Lucht, Journal of The Electrochemical Society, 161, A1001 (2014).

4. R. Petibon, J. Xia, L. Ma, M. K. G. Bauer, K. J. Nelson, and J. R. Dahn, Journal of The Electrochemical Society, 163, A2571 (2016)

5. J. Xia, R. Petibon, D. Xiong, L. Ma, and J. R. Dahn, Journal of Power Sources, 328 124 (2016).

6. S. S. Zhang, Journal of Power Sources, 162, 1379 (2006)

7. K. Abe, in Electrolytes for Lithium and Lithium Ion Batteries, Richard T Jow, Kang Xu, Oleg Borodin, and M. Ue, Editors, Springer-Verlag New York (2014).

8. Y. Ein-Eli, S. R. Thomas, and V. R. Koch, Journal of The Electrochemical Society, 143, L195 (1996).

9. Y. Ein-Eli, S. R. Thomas, and V. R. Koch, Journal of The Electrochemical Society, 144, 1159 (1997).

10. Y. Ein-Eli, Journal of Electroanalytical Chemistry, 531, 95 (2002).

11. J. O. Besenhard, M. W. Wagner, M. Winter, A. D. Jannakoudakis, P. D. Jannakoudakis, and E. Theodoridou, Journal of Power Sources, 44, 413 (1993).

12. M. W. Wagner, C. Liebenow, and J. O. Besenhard, Journal of Power Sources, 68 , 328 (1997).

13. G. H. Wrodnigg, J. O. Besenhard, and M. Winter, Journal of The Electrochemical Society, 146, 470 (1999).

14. G. H. Wrodnigg, J. O. Besenhard, and M. Winter, Journal of Power Sources, 97-98, 592 (2001).

15. B. Li, M. Xu, T. Li, W. Li, and S. Hu, Electrochemistry Communications, 17, 92 (2012).

16. M. Q. Xu, W. S. Li, X. X. Zuo, J. S. Liu, and X. Xu, Journal of Power Sources, 174 705 (2007).

17. R. Wagner, S. Brox, J. Kasnatscheew, D. R. Gallus, M. Amereller, I. Cekic-Laskovic, and M. Winter, Electrochemistry Communications, 40, 80 (2014).

18. J. Xia, N. N. Sinha, L. P. Chen, and J. R. Dahn, Journal of the Electrochemical Society, 161, A264 (2013).

19. M. Xu, W. Li, and B. L. Lucht, Journal of Power Sources, 193, 804 (2009).

20. B. Zhang, M. Metzger, S. Solchenbach, M. Payne, S. Meini, H. A. Gasteiger, A. Garsuch, and B. L. Lucht, The Journal of Physical Chemistry C, 119, 11337 (2015).

21. M. Xu, L. Zhou, Y. Dong, Y. Chen, J. Demeaux, A. D. MacIntosh, A. Garsuch, and B. L. Lucht, Energy \& Environmental Science, 9, 1308 (2016).
22. M. Nie,L. Ma, J. Xia, A. Xiao, W. M. Lamanna, K. Smith, and J. R. Dahn, Journal of The Electrochemical Society, 163, A2124 (2016).

23. C. L. Campion, W. Li, and B. L. Lucht, Journal of The Electrochemical Society, 152, A2327 (2005)

24. M. J. Frisch, G. W. Trucks, H. B. Schlegel, G. E. Scuseria, M. A. Robb, J. R. Cheeseman, J. A. Montgomery, T. Vreven, K. N. Kudin, J. C. Burant, J. M. Millam, S. S. Iyengar, J. Tomasi, V. Barone, B. Mennucci, M. Cossi, G. Scalmani, N. Rega, G. A. Petersson, H. Nakatsuji, M. Hada, M. Ehara, K. Toyota, R. Fukuda, J. Hasegawa, M. Ishida, T. Nakajima, Y. Honda, O. Kitao, H. Nakai, M. Klene, X. Li, J. E. Knox, H. P. Hratchian, J. B. Cross, V. Bakken, C. Adamo, J. Jaramillo, R. Gomperts, R. E. Stratmann, O. Yazyev, A. J. Austin, R. Cammi, C. Pomelli, J. W. Ochterski, P. Y. Ayala, K. Morokuma, G. A. Voth, P. Salvador, J. J. Dannenberg, V. G. Zakrzewski, S. Dapprich, A. D. Daniels, M. C. Strain, O. Farkas, D. K. Malick, A. D. Rabuck, K. Raghavachari, J. B. Foresman, J. V. Ortiz, Q. Cui, A. G. Baboul, S. Clifford, J. Cioslowski, B. B. Stefanov, G. Liu, A. Liashenko, P. Piskorz, I. Komaromi, R. L. Martin, D. J. Fox, T. Keith, A. Laham, C. Y. Peng, A. Nanayakkara, M. Challacombe, P. M. W. Gill, B. Johnson, W. Chen, M. W. Wong, C. Gonzalez, and J. A. Pople, Gaussian 03, Revision C.02, in (2003).

25. V. A. Agubra and J. W. Fergus, Journal of Power Sources, 268, 153 (2014).

26. G. C. Chung, H. J. Kim, S. I. Yu, S. H. Jun, J. w. Choi, and M. H. Kim, Journal of The Electrochemical Society, 147, 4391 (2000).

27. L. Castro, R. Dedryveère, J. B. Ledeuil, J. Breéger, C. Tessier, and D. Gonbeau, Journal of The Electrochemical Society, 159, A357 (2012).

28. L. Bodenes, R. Dedryvere, H. Martinez, F. Fischer, C. Tessier, and J. P. Peres, Journal of the Electrochemical Society, 159, A1739 (2012).

29. N. Andreu, D. Flahaut, R. Dedryvere, M. Minvielle, H. Martinez, and D. Gonbeau, ACS applied materials \& interfaces, 7, 6629 (2015).

30. B. Li, M. Xu, B. Li, Y. Liu, L. Yang, W. Li, and S. Hu, Electrochimica Acta, 105, 1 (2013).

31. H. Wang, C. Zhang, Z. Liu, L. Wang, P. Han, H. Xu, K. Zhang, S. Dong, J. Yao, and G. Cui, Journal of Materials Chemistry, 21, 5430 (2011).

32. S. Men, D. S. Mitchell, K. R. Lovelock, and P. Licence, Chemphyschem : a European journal of chemical physics and physical chemistry, 16, 2211 (2015).

33. J. Demeaux, D. Lemordant, M. Caillon-Caravanier, H. Galiano, and B. Claude-Montigny, Electrochimica Acta, 89, 163 (2013)

34. J. Demeaux, D. Lemordant, H. Galiano, M. Caillon-Caravanier, and B. Claude-Montigny, Electrochimica Acta, 116, 271 (2014).

35. R. Dedryveère, D. Foix, S. Franger, S. Patoux, L. Daniel, and D. Gonbeau, The Journal of Physical Chemistry C, 114, 10999 (2010).

36. H. Bouayad, Z. Wang, N. Dupré, R. Dedryvère, D. Foix, S. Franger, J. F. Martin L. Boutafa, S. Patoux, D. Gonbeau, and D. Guyomard, The Journal of Physical Chemistry C, 118, 4634 (2014).

37. J. Pires, A. Castets, L. Timperman, J. Santos-Peña, E. Dumont, S. Levasseur, C. Tessier, R. Dedryvère, and M. Anouti, Journal of Power Sources, 296, 413 (2015).

38. S. Malmgren, K. Ciosek, M. Hahlin, T. Gustafsson, M. Gorgoi, H. Rensmo, and K. Edström, Electrochimica Acta, 97, 23 (2013).

39. L. Madec, R. Petibon, K. Tasaki, J. Xia, J. P. Sun, I. G. Hill, and J. R. Dahn, Physical chemistry chemical physics, 17, 27062 (2015).

40. G. Zhou, L. -C. Yin, D. -W. Wang, L. Li, S. Pei, I. R. Gentle, F. Li, and H. -M. Cheng, ACS Nano, 7, 5367 (2013).

41. R. Demir-Cakan, M. Morcrette, Gangulibabu, A. Guéguen, R. Dedryvère, and J. -M. Tarascon, Energy \& Environmental Science, 6, 176 (2013). 